\title{
Cultural Diplomacy in Action: The United States' Export of Hip Hop to the Muslim World ${ }^{2}$
}

\begin{abstract}
Among its other manifestations, the globalization has brought unparalleled development of the music platforms, logistically supported by the widespreadness of Internet. This article elaborates on the specific type of music-based diplomacy: hip hop diplomacy. After placing in the theoretical and practical context, the author analyzes the usage of hip hop diplomacy by the United States, particularly, in the Muslim world. I argue that while hip hop diplomacy seems to be a smart 'new edition' to the US cultural diplomacy portfolio, it suffers from the same systemic paradox as its Cold War's predecessor - jazz diplomacy.
\end{abstract}

Key words: hip hop, cultural diplomacy, United States, music diplomacy, Muslim world

\section{Introduction}

Among its other manifestations, the globalization has brought unparalleled development of the music platforms, logistically supported by the widespreadness of Internet. Both descriptive and analytical, this article elaborates on the specific type of music-based diplomacy: hip hop diplomacy. After placing in the theoretical and

1 PhD student / Independent Advisor, lukaglusac@gmail.com

2 The views expressed in this paper do not necessarily reflect the positions of the Protector of Citizens. 
practical context, I seek to analyze the usage of hip hop diplomacy by the United States, particularly, in the Muslim world. I argue that while hip hop diplomacy seems to be a smart 'new edition' to the U.S. public diplomacy portfolio, it suffers from the same paradox as its Cold War's predecessor - jazz diplomacy.

The article is organized in three main parts. Firstly, I introduce hip hop as a subculture, music genre and an emerging academic field, followed by a short description of the relevance of Islam to hip hop. In the second part, I situate hip hop diplomacy in a wider context of public and cultural diplomacy. In the most elaborated third part, I present the case of the U.S. hip hop diplomacy in the Muslim world and, finally, close with its strengths and weaknesses.

\section{Setting the Scene: Hip Hop from Bronx to Beirut}

The history of Hip Hop begins in the Bronx suburbs of New York City in the 1970s. The key elements which at that time came together and started to form an emerging Hip Hop culture are DJing (deejaying), MCing (rap music), graffiti art and dance (most notably breaking or break dancing). Motley and Henderson (2008) gave useful short definitions of all main hip hop elements. 'Graffiti is the visual art and break dancing is an element of the performance art of the hip hop culture. The disk jockey (DJ) selects and blends the background music tracks. Originally, the master of ceremonies (MC) introduced the DJ and the music. To generate excitement, the MC would encourage and greet the audience with verbal exchanges' (Motley and Henderson 2008: 245). Over time, that practice developed into a style called 'rapping' (for a useful historical account, see Hager 1984). An average rap song consists of the rhythmic lyrics spoken or chanted over a (usually) syncopated and repetitive beat.

Hip hop has evolved during the 1970s as a liberation movement, or as Emmet put it: 'it was a next-generation civil (human) rights movement sparked by ostracized, marginalized, and oppressed inner-city youth' $(2006,1)$. It has embraced the traditions of U.S.-born Blacks and first- and second-generation Latinos as well as people of Caribbean origin. 'It is a means and method of expression thriving on social commentary, political critique, economic analysis, religious exegesis, and street awareness while combating long-standing issues of racial prejudice, cultural persecution, and 
social, economic, and political disparities' (Emmet 2006, 1). Over decades, it evolved from a local phenomenon addressing the needs and desires of poor inner-city youth to global, multi-billion-dollar institution that has virtually changed the rules of the game, i.e. the nature of the music and entertainment industries. In a recent study on the evolution of popular music in the USA, Mauch and others (2015) analyzed approximately 17.000 recordings that appeared on the US Billboard Hot 100 top list between 1960 and 2010. They concluded that the emergence of hip-hop, which crash-landed in the charts in 1991, reinvented the musical landscape like nothing before or since. In addition, the Spotify - one of the world's leading commercial music streaming website - has created a live 'musical map of the world', analyzing nearly 20 billion tracks to show localized listening trends for over 1000 cities. The map revealed that hip hop is the world's top genre, showing up on playlists more than all others, regardless of geography or language (The Independent 2015).

In addition to being seen as a subculture, Hip Hop has also emerged as an academic subfield. Since 1991 when Howard University, a historically black college, introduced the first specific hip hop course, over 300 courses at US universities in some related to hip hop way have been established, including those at top-ranked universities, such as Harvard, Penn State, USC, UCLA, Stanford, Duke, Princeton, and NYU. Hip hop-related books have appeared on more than 700 college syllabi (The Huffington Post 2013). Furthermore, hundreds of dissertations about hip-hop have been written $^{3}$, specialized journal were launched (i.e. Journal of Hip Hop Studies), followed by a huge proliferation of academic conferences and the development of readers and anthological texts (Hill and Petchauer 2013; Forman and Neal 2004; Jackson and Anderson 2009). Moreover, the establishment of the Hip Hop Archive and Research Institute at Harvard University with the most comprehensive bibliography on hip hop ${ }^{4}$ certainly helped raising the relevance, visibility and academic interest to the field.

As noted by literally all hip hop scholars, there is often confusion over the terms rap music and Hip Hop. The general trend in the

3 The first American PhD dissertation about hip-hop was written in 1989 by Tricia Rose. Her dissertation was subsequently published in 1994 as "Black Noise" and is widely viewed as one of the masterpieces of the academic hip-hop genre. According to: Söderman 2013.

4 Visit the bibliography at http://hiphoparchive.org/scholarship/bibliography, last modified April 30, 2016. 
academic literature defines Hip Hop as a specific cultural group or youth arts movement, while rap is the musical expression of that social group (Keyes 2002). To the extent that rap music is the music of Hip Hop, the terms rap music and hip hop music can be used interchangeably, as in this article. I will borrow from Keyes spelling distinctions between hip hop and Hip Hop (Keyes 1996, 231). I use the former for music direction and the latter to denote a culture.

For the purposes of this article, I will use the distinction between mainstream and underground rap. The mainstream covers the entertainment, materialistic, and gangster aspects of the genre, while the underground rap relates to social, political and religious topics.

Religious rap, one of sub-genres of the underground rap, can be defined as 'a musical representation of a faith as a means to praise, entertain, or recruit listeners to the faith' (Jones 2009, 10-11). Religious rap is usually divided into Christian and Muslim rap, but other 'congregational sub-genres' are not to be excluded.

'Rap's got religion and that religion is Islam'

(Ahearn 1991 as cited in Samy Alim 2006, 25)

The question of permissibility of music in Islam has drawn sizable attention among scholars. Some of them say it is haram (forbidden) in all cases, some say that only a-capella is allowed, but it seems that majority stands by the opinion that music is halal (permissible) as long as it is free from content which violates the basic principles of Islam, i.e. sex, drugs, violence, profanity. ${ }^{5}$

While the Muslim rap is hard to find within the mainstream rap music, i.e. on the commercial top lists, it would be utterly wrong to underestimate its significance to the origins, evolution and contemporary practice of hip hop. In fact, as early as in 1991, well-known hip hop journalist, Harry Allen, has described Islam as Hip Hop's 'official religion'. Despite that, Islam's dynamic presence and important role in the Hip Hop have been notably unexplored. The first study of Hip Hop to highlight the widespread practice of Islam in Hip Hop, its 'unique modern tones', and how it has impacted the philosophy of key hip hop players, was 'Nation Conscious Rap: The Hip Hop Vision' (Spady and Eure 1991 as cited in Samy Alim 2006, 23). Some of the most recognized rap artists such as Rakim, Brand Nubian, KRS-1, Afrika Bambaataa or Public Enemy have all introduced some version of Islam to Pop Culture (Toop, 1984).

5 For more on permissibility of music in Islam see, for example: Khabeer 2007. 
Stanford scholar H. Samy Alim seems right when saying that:

'Given that Islam has been a normative practice in Black America for centuries since slavery, and that Black American popular culture from the Blues to BeBop has always contained strong elements of social protest, the dynamic presence of Islam in the Hip Hop should not come as a surprise. In fact, the lack of a Muslim presence in Hip Hop would represent an astonishing rupture from Black American popular cultural tradition' $(2006,27)$.

\section{Diplomacy: Public, Cultural, Music, Hip Hop}

The Google search of 'Hip Hop Diplomacy' generates over 400.000 results. The article by Hisham Aidi published in Foreign Affairs in 2014 tops the list. Hip hop diplomacy is part of a wider notion of public diplomacy.

As noted by many scholars (Gregory 2008, 275; Cull 2006; Roberts 2006), the term public diplomacy was adopted by practitioners in the United States in the 1970s as an alternative to propaganda, which had negative connotations, and as an umbrella label for the U.S. government's international information, cultural relations, and broadcasting activities. Gregory observes that it is a term that describes ways and means by which states, associations of states, and non-state actors understand cultures, attitudes, and behavior; build and manage relationships; and influence opinions and actions to advance their interests and values' (Gregory 2008, 276; see also Tuch 1990, 190).

Most studies in public diplomacy are historical, and they overwhelmingly deal with the U.S. experiences during the Cold war, including the ones drawn from anecdotal sources and personal testimonies of former diplomats. While public diplomacy is often confused with propaganda, public relations (PR), international public relations (IPR), psychological warfare, or public affairs, it is in most cases equated with another US product - 'soft power', as famously coined by Joseph Nye $(1990 ; 2004)$. That is despite the fact that 'public diplomacy today encompasses much more substance than these terms convey individually' (Gilboa 2008, 56). That especially refers to propaganda. Nye, himself, stated 'skeptics who treat the term public diplomacy as a mere euphemism for propaganda miss the point; conveying information and selling a positive image 
is part of it, but public diplomacy also involves building long-term relationships that create an enabling environment for government policies' $(2008,101)$. In Nye's account of soft power, it is an ability to shape the preferences of others, resting primarily on three resources, where culture is the first, followed by the political values and foreign policies. ${ }^{6}$ It seems worthy to point out that cultural attractiveness per se is not soft power on its own, but 'can be a soft power resource, provided it is deployed to achieve clearly defined policy objectives under a thought-out strategy' (Ang, Isar and Mar 2015, 368).

From the public diplomacy practice emerged a narrower notion of 'cultural diplomacy', as coined by Milton Cummings as 'the exchange of ideas, information, values, systems, traditions, beliefs, and other aspects of culture, with the intention of fostering mutual understanding' $(2003,1)$. A landmark US Department of State report, in fact, defines cultural diplomacy as the linchpin of public diplomacy, because 'it is in cultural activities that a nation's idea of itself is best represented; cultural diplomacy can enhance national security in subtle, wide-ranging, and sustainable ways' $(2005,1)$.

It is important to take note that cultural diplomacy 'should not be considered an accessory of state's foreign policymaking process and not be limited to referring to state policy alone' (Jorgensen in Chay 1990). Nonetheless, in this article I cover primarily the state policy, leaning on the view that 'cultural diplomacy is a governmental practice that operates in the name of a clearly defined ethos of national or local representation, in a space where nationalism and internationalism merge' (Ang, Isar and Mar 2015, 367).

After completing a survey regarding the effectiveness of cultural diplomacy, Arndt (2005) observed that it is a cost effective practice considering its outcomes and impacts on international ties between countries. The integral part and the most visible expression of the cultural diplomacy is music, i.e. so-called music diplomacy articulated through deploying selected musicians abroad for the purposes of reaching the goals of public diplomacy. Its most known category is so-called jazz diplomacy, as used by the US during the Cold War. In recent years, hip hop diplomacy has started to assume the leading role, as to be demonstrated below.

6 See more: Nye 2004. 


\section{United States and Music Diplomacy: from Satchmo to Chen Lo}

Cultural diplomacy and music in particular has played an important and unique role in American foreign diplomacy for many years. Indeed, as early as in 1954, the President Dwight D. Eisenhower called for the creation of a worldwide cultural exchange program for the performing arts to improve the world's perception of American cultural and political life (Davenport 2009, 3). As Nicholas Cull has deftly shown, cultural diplomacy became part of an expansive American effort to invest the $\mathrm{P}$ factor-the 'psychological dimension of power'-to wage the Cold War $(2008,81)$ and respond to Soviet public campaign, painting 'Americans as racist and segregationist' (52). The most vivid and researched expression of the US Cold War foreign cultural efforts has been the so-called jazz diplomacy, that 'profoundly helped reshape perceptions of the American identity throughout the world' (Davenport 2009, 4), with the help of artists such as Duke Ellington, Dizzy Gillespie, Louis 'Satchmo' Armstrong, Dave Brubeck and others. They have travelled around the world, playing thousands of concerts, mostly between mid-50s and early '70s, particularly in the states whose allegiances were not well defined or that were perceived as being at risk of aligning with the Soviet Union. Dave and Iola Brubeck, in collaboration with Louis Armstrong and his band gave arguably the best description of jazz musicians' experience in their jazz musical 'The Real Ambassadors' (1961).

Lisa Davenport captured the importance of jazz in these decades, saying '[jazz] held a unique place in American cultural policy' $(2009,5)$. One could add - 'in American foreign policy, as well', as it has been integral part of the U.S. containment policy. The containment policy was introduced in the late 40 s, following the infamous George Kennan's Long Telegram, later published under the title 'Sources of Soviet Conduct' in Foreign Affairs (1947) and the National Security Council Report 68 (NSC-68). Two documents shaped U.S. foreign policy in the next twenty years and both advocated for non-military means to contain the Soviet influence, making culture its important component.

With the end of the Cold War, the foreign cultural program of that scale seemed to be redundant, but still continued to operate passively in the background during the 1990s, lamenting over its meaning in a globalizing post-Cold War world. The infamous US 
Information Agency which was responsible for majority of the Cold War cultural diplomacy endeavors, or as Albro put it 'charged with "telling America's story" to the world' $(2015,382)$ ceased to exist in 1999.

Three years into the War of Terror, that has followed the terrorist attacks on 11 September 2001, a respected Pew Research Center published its Global Attitudes survey. The results can be summed as follows. 'Majorities in many Muslim nations believe America's war on terrorism is really an effort to control Mideast oil or to dominate the world. The war on terrorism was a smokescreen for a campaign against unfriendly Muslim governments' (Pew Research Center 2008). In George W. Bush's existing year as the President of the USA, the same survey reported that in the view of much of the world, the United States has played the role of bully in the school yard, throwing its weight around with little regard for others' interests' (Pew Research Center 2008). In addition to public surveys, the academia has also been very critical to the US post-9/11 cultural diplomacy. Schneider has claimed that cultural/public diplomacy has been used by the U.S. government in a reactionary fashion rather than as a means of consistent engagement with foreign audiences (2006, 192). Another scholar argued that American thinking on public diplomacy became largely an introspective examination of public diplomacy's relevance to terrorism and pervasive anti-Americanism in a post-9/11 world (Gregory 2008, 275).

As a part of the efforts of changing the negative U.S. picture abroad, especially in the Muslim world, the first US Undersecretary for Public Diplomacy after 9/11, Charlotte Beers, known as a marketing guru, has launched, what ended up to be very short-lived, soft power-motivated 'Shared Values Initiative', aimed at the Muslim audience in the Middle East. Beers' attempt to use business marketing strategy to increase American favorability in the Muslim world failed spectacularly. A 'more pictures, less words' approach followed by a new State Department website campaign centered with infomercial-like videos of Middle East-born Americans living happily in USA and advocating so-called U.S. values, i.e. freedom or religious pluralism, has been doomed to fail. As Albro noted, 'it met almost immediate opposition from governments in the Middle East, with Egypt, Lebanon and Jordan refusing to air the videos' $(2015,387)$. Snow captured the essential reason of Shared Values Initiative's failure, emphasizing that it portrayed the Muslim Americans as products, and while that was perhaps successful in US domestic market, proved to be completely wrong 'take home message' for 
here 'target audience' - conservative Middle East societies (2003, 96; 105). Instead of such product selling campaign, the U.S. has needed a convincing two-way approach, that would give chance to target audience to act as an active counterpart, not just a pure recipient.

Returning to its most successful campaign to date, the State Department decided to re-activate its music diplomacy program in 2005. The new program called 'The Rhythm Road' was modeled on the jazz diplomacy initiative, except that in the War on Terror, hip hop plays the central role of countering 'poor perceptions' of the U.S. (Aidi, 2011). The program began sending "hip hop envoys" - rappers, dancers, DJs - to perform and speak in different parts of Africa, Asia and the Middle East, covering the majority of the Muslim world. Since 2006, the program has sent more than 100 musicians on tours to 97 different countries, most of them outside the immediate reach of American music. Ten performers are chosen each year from a comprehensive audition process who then tour around the world, staying in each county around one week. The program is implemented by Jazz at Lincoln Center in partnership with the U.S. Department of State's Bureau of Educational and Cultural Affairs. Adrian Ellis, Executive Director of Jazz at Lincoln Center, defined transnational communication, through the language of music, as the ultimate objective in the Rhythm Road program (Constant 2011).

The (un)spoken goals of the U.S. hip hop diplomacy

In 2010, rapper Chen Lo was sent to perform in Damascus. Following his performance, U.S. secretary of state Hillary Clinton was asked by CBS News about U.S. diplomacy's recent embrace of hip hop. 'Hip hop is America', she said, noting that rap and other musical forms could help 'rebuild the image' of the United States (CBS News 2010). The artists stage performances and hold workshops. This emphasis on making connections between bands and local audiences is one of the biggest differences between the old jazz ambassadors and the Rhythm Road program (The Wall Street Journal 2010). The new program includes much higher number of workshops, lectures, round tables and master classes, focusing on smaller events and smaller groups, enabling a more in-depth and personalized approach.

'Hip hop ambassadors who are Muslims talk to local media about being Muslim in the U.S. The tours aim not only to exhi- 
bit the integration of American Muslims, but also, according to planners, to promote democracy and foster dissent' (Aidi, 2011). Speaking on the preferred outcome of the program, Clinton said you have to bet at the end of the day, people will choose freedom over tyranny if they're given a choice', highlighting that cultural diplomacy is a complex game of 'multidimensional chess'. 'Hip hop can be a chess piece?' asked the interviewer. 'Absolutely!' responded the secretary of state (CBS News 2010).

Clinton seized the very essence of the entire U.S. 'new music diplomacy' endeavor. It is aimed at changing young Muslims' negative U.S. perception, at their homes. The U.S. smartly chooses the underground over mainstream rap artists and particularly selects the moderate Muslim, socially engaged, rappers, known for their strong lyrical content rather than catchy music beat, for at least two obvious reasons. Firstly, sending so-called 'bling bling ${ }^{77}$ rappers would definitely not help changing the 'Infidel America' picture, as the success of public diplomacy depends on the attractiveness of country's culture, values, and policies, to draw again from Nye. 'Exporting Hollywood films full of nudity and violence to conservative Muslim countries may produce repulsion rather than soft power' (Nye 2008, 95). In other words, local audience cannot relate to aggressive, offensive, gangsta American rap. ${ }^{8}$ Secondly, who would be best to testify on the integration of the Muslims in America than believing American Muslims? Here it is important to notice that opposite to infomercials of Shared Values campaign, the Rhythm Road is concentrated on a live presence of musicians abroad, enabling the two-way communication. With a live presence comes a live communication. According to Ari Roland, international jazz musician, who has traveled into twenty-six countries as a part of the program, despite being supported by the government, the Rhythm Road's participants do not have to agree with every single policy by the administration. He argued that on every tour he has been a part of, the State Department 'made very clear to us that we were private United States citizens who were completely free to express our views and opinions on any matters' (Constant 2011). The goal, nevertheless, stays the same - promotion of other, moderate, religiously tolerant America, open to Muslims. The music

$7 \quad$ Bling bling is the US rap slang describing expensive, ostentatious clothing and jewelry and the style or materialistic attitudes associated with them.

8 Gangsta rap is a subgenre of rap with a lyrical focus on the activities of illegal street gangs and the 'thug' or 'gangsta' (gangster) lifestyle. 
of majority of rappers involved in the Rhythm Road reflects the everyday life of common people and the most pressing issues they encountered with - political, social, and economical.

\section{Paradoxes of the U.S. hip hop diplomacy}

The U.S. specially aims to deploy rappers in the regions/countries where they would like to see regime change. At the White House Millennium event honoring jazz in 2000, Vaclav Havel said 'music is the enemy of totalitarianism' (Schneider 2008). In the new U.S. vision, hip hop is the face and sound of that 'enemy'. Its provocative and engaging massage should serve as a boost for youth mobilization and politically-conscious activism. H. Samy Alim (2005) calls the Muslim rappers - both American performing abroad and foreign ones active in their respective countries - 'verbal mujahidins' and their activism - 'transglobal Hip Hop umma'. As media freedoms in the Muslim world are known to be at least questionable, he sees rappers' activities as alternative media source narrating the beliefs and experiences of the nation (umma). ${ }^{9}$ According to him, their very experiences, when verbalized, represent a discursive struggle against oppression (Samy Alim, 2006, 21). While the general hip hop audience has widened immensely through the years, the target audience of Muslim rap is still predominantly conservative, i.e. young Muslims of lower economic status, socially excluded, often politically oppressed and most responsive to the calls for change. This usage of hip hop to help generating a critical mass for inducing political change, like with other non-violent methods, calls for comprehensive and context-sensitive approach. Despite a large body of literature on non-violent political change, equipped with concrete tools, methods and lessons-learned ${ }^{10}$ representing the non-violent struggle as a success story, the U.S. is known for influencing the violent foreign regime changes throughout its history. ${ }^{11}$ Recent examples, most notably Arab Spring, show that producing the regime change is much easier that making sure that the new one will play by the Western rules. While the West has prompted the changes, the actual outcome is far from positive. The vast majority of population is not only exposed to the same problems as before

9 Alternatively spelled as 'ummah' meaning the whole community (nation) of Muslims bound together by ties of religion.

10 The work of Gene Sharp alone is sufficiently instructive: Sharp 2005 and 1973.

11 For a good overview see: Kinzer 2006. 
- poverty and oppression - but has had to flee for their life. The ones that stayed are under overwhelming influence of the extreme fundamentalists and are becoming increasingly prone to violent radicalization. ${ }^{12}$ That is particularly important when adding that, as Ang, Isar and Mar have argued, 'in a world where opportunities for global exchange and networking are ubiquitous, the rise of counterhegemonic forms of cultural diplomacy, driven by forces that are working against established nation-states, is a distinct possibility' $(2015,375)$. For some time, the so-called Islamic state (ISIS) has implemented soft power-like activities, in an extreme form, of course.

There is another paradox of the U.S. foreign policy. In this article central - music diplomacy - suffers from the paradox of its own. In her critically acclaimed book 'Jazz Diplomacy: Promoting America in the Cold War Era', Davenport has neatly observed that as the United States propelled jazz abroad, jazz diplomacy transformed relations between nations and created a bold Cold War paradox: the cultural expression of one of the nation's most oppressed minorities came to symbolize the cultural superiority of American democracy (2009, 5; see also Bratton 1998). At the time, Soviet propaganda highlighted the fact that 'the US protected democratic rights for whites, while it violently denied those rights to African America' (Davenport 2009: 11). ${ }^{13}$ That paradox is easily observed today, as well, given that the profile of hip hop envoy's artists in sense of race, age and social background is essentially the same as of jazz musicians back in the day. Additionally, despite being partners of the State Department in music diplomacy efforts abroad, at home, rappers are of particular interest to some other branches of the government, namely Federal Bureau of Investigation (FBI) and police departments of major cities, most notably New York and Miami. As noted by Shepherd, 'the FBI in collusion with the New York Police Department (NYPD) have been so adamant about profiling (and

12 In this article, the violent radicalization is to be described as a process of individual evolution towards adopting certain ideas and sometimes the use of violence and terrorist tactics to achieve political goals. Number of studies on the violent radicalization has been published in recent years. Particularly informative source is the journal 'Terrorism and Political Violence. See, for example, Bartlett and Miller 2012 and Sedgwick 2010.

13 Additionally, at the time when Duke Ellington was one of the leaders of the US efforts abroad, domestically the Government through the congressionally-approved budget of the National Endowment of Arts allocated 70 times more funds for symphony orchestras than to jazz ( $\$ 3.500 .000$ to $\$ 50,000)$. See more in Walton 1972, according to Bratton 1998, 19. 
taking down) well-recognized stars of the genre. The 'hip hop cops' are also known as the "rap task force", and they exist solely for the surveillance of rappers' (Shepherd 2012; see also RHHR 2013). Such particular FBI's attention on rappers is not a novelty. As early as in 1989, the FBI issued an infamous letter to the recording house of a rap group N.W.A. because of their hit song 'Fuck tha police', arguing that it encourages violence against and disrespect for the law enforcement officers (see more in Hochman 1989). While the song has obviously been a lyrical form of protest against police brutality and racial profiling, and in fact, expression of approval of violence against police, the FBI's letter has been widely considered as an attack on the freedom of expression. While in 1989 rappers have almost exclusively been treated as a threat, today, they are often perceived as menace at home, but desired ambassadors abroad.

\section{Conclusion}

Despite shown difficulties to communicate its soft power to the audience in the Middle East, the U.S. Government has to continue to lead those efforts, not the entertainment sector. As Bayles (2014) has suggested, 'allowing the entertainment sector to assume the job of communicating the U.S.'s image to the world has been disastrous, since such cultural content is too often violent, sexualized, anti-religious, politically cynical, and celebrates rootless individual freedoms outside of any social or collective context' (Albro 2015, 388). The target audience in the Middle East is the last that should be exposed to such contents.

There is no doubt that the Rhythm Road is far more successful program than the Shared Values. Its focus on rap music has been innovative and thoughtful, given the target audience in the Middle East. However, as argued here, the usage of rappers for cultural diplomacy's goals suffers from the same paradox as the jazz diplomacy of the Cold War. The same oppressed subcultural group in the U.S. is used to promote it abroad.

Often unspoken, but certainly necessary precondition for a successful cultural diplomacy is a consistency, both in domestic and foreign policy. If cultural activities are in obvious disparity with other foreign policy manifestations in the region, than the audience will interpret them as insincere, annulling its attractiveness. 
Similarly, attempt to promote something abroad, while having a problem to implement it fully domestically, would most likely cause suspicion. That seems to be a problem of the U.S. export of hip hop to the Muslim world, as shown in this article.

When recent high profile cases of racial riots caused by murders of black civilians by white police officers are added to that, the U.S. seems to have not that impressive 'good practice' to export. If lessons are learned, than they sound more like a product to export.

\section{Bibliography}

Aidi, H. (2011) "Leveraging hip hop in US foreign policy", Al Jazeera, November 07, [online] Available at: http://www.aljazeera.com/ indepth/opinion/2011/10/2011103091018299924.html [Accessed 30 April 2016].

Aidi, H. (2014) "Hip-Hop Diplomacy: U.S. Cultural Diplomacy Enters a New Era", Foreign Affairs, April 16, [online] Available at: https:// www.foreignaffairs.com/articles/united-states/2014-04-16/hip-hopdiplomacy [Accessed 30 April 2016].

Albro, R. (2015) "The disjunction of image and word in US and Chinese soft power projection", International Journal of Cultural Policy, 21(4): pp. 382-399.

Allen, H. (1991) "Righteous indignation: Rappers talk about the strength of Hip-Hop and Islam", The Source 48 (March/April): pp. 48-53.

Ang, I, Y. Raj Isar and P. Mar (2015) "Cultural diplomacy: beyond the national interest?", International Journal of Cultural Policy, 21(4): pp. 365-381.

Arndt, R.T. (2005) The First Resort of Kings: American Cultural Diplomacy in the Twentieth Century, Washington D.C: Potomac Books.

Bartlett, J. and C. Miller (2012) "The Edge of Violence: Towards Telling the Difference Between Violent and Non-Violent Radicalization", Terrorism and Political Violence, 24(1): pp. 1-21.

Bayles, M. (2014) Through a screen darkly: popular culture, public diplomacy, and America's image abroad, New Haven, CT: Yale University Press.

Bratton, E. (1998) "The Sound of Freedom: Jazz and the Cold War", Crisis, February/March: pp. 14-19.

Chang, J. (2006) Review: Keeping It Real: Interpreting Hip-Hop", College English, 68(5): pp. 545-554. 
Channick, J. (2005) “The Artist as Cultural Diplomat", American Theater Magazine, May/June.

Chay, J. (ed.) (1990) Culture and International Relations, New York: Praeger Publishers.

Constant, L. (2011) "A Different Kind of P2P: The Rhythm Road: American Music Abroad" The Huffington Post, May 25, [online] Available at: http://www.huffingtonpost.com/linda-constant/a-different-kind-ofp2p-t_b_757662.html [Accessed 30 April 2016].

Cooke, M. and B. Lawrence (eds.) (2005) Muslim Networks: From Hajj to Hip Hop. NC: UNC Press.

Cull, N.J. (2006) "Public diplomacy before Gullion: The evolution of a phrase"Public Diplomacy Blog, April 18, [online] Available at: http://uscpublicdiplomacy.com/index.php/newsroom/pdblog_ detail/060418_public_diplomacy_before_gullion_the_evolution_ of_a_phrase/ [Accessed 30 April 2016].

Cull, N. J. (2008) The Cold War and the United States Information Agency: American Propaganda and Public Diplomacy: 1945-1989, Cambridge: Cambridge University Press.

Cummings, M. (2003) Cultural Diplomacy and the United States Government: a Survey, Washington D.C.: Center for Arts and Culture.

Da Fonseca-Wollheim, C. (2010) "America's Musical Ambassadors" The Wall Street Journal, June 17, [online] Available at: http://www.wsj. com/articles/SB10001424052748704324304575306603221333096 [Accessed 30 April 2016].

Davenport, L.E. (2009) Jazz Diplomacy: Promoting America in the Cold War Era, Jackson: University Press of Mississippi.

Escobedo S. J. (2012) "Hip-Hop Diplomacy? How the State Department Uses Rap to Spread Propaganda Abroad" Alternet, January 04, [online] Available at: http://www.alternet.org/story/153662/hiphop_diplomacy_how_the_state_department_uses_rap_to_spread_ propaganda_abroad\# [Accessed 30 April 2016].

Forman, M. and M. Anthony Neal (eds.) (2004) That's the Joint!: the HipHop Studies Reader,. New York: Routledge.

Gilboa, E. (2008) "Searching for a Theory of Public Diplomacy", The Annals of the American Academy of Political and Social Science, 616: pp. 55-77.

Gregory, B. (2008) "Public Diplomacy: Sunrise of an Academic Field", The Annals of the American Academy of Political and Social Science, 616: pp. 274-290. 
Hager, S. (1984) Hip hop: the illustrated history of break dancing, rap music, and graffiti, New York: St. Martin's Press.

Hochman, S. (1989) "Compton Rappers Versus the Letter of the Law: FBI Claims Song by N.W.A. Advocates Violence on Police” Los Angeles Times, October 05, [online] Available at: http://articles. latimes.com/1989-10-05/entertainment/ca-1046_1_law-enforcement [Accessed 30 April 2016].

Lamont Hill, M. and E. Petchauer (eds.) (2013) Schooling Hip-Hop: Expanding Hip-hop Based Education across the Curriculum, New York: Teachers College Press.

Hooton, C. (2015) "Hip-hop is the most listened to genre in the world, according to Spotify analysis of 20 billion tracks" The Independent, July 14, [online] Available at: Http://Www.Independent.Co.Uk/ Arts-Entertainment/Music/News/Hiphop-Is-The-Most-ListenedTo-Genre-In-The-World-According-To-Spotify-Analysis-Of-20Billion-Tracks-10388091.Html [Accessed 30 April 2016].

Jackson, B. and S. Anderson (2009) "Hip Hop Culture around the Globe: Implications for Teaching”, Black History Bulletin, 72(1): pp. 22-28.

Jones, J.L. (2009) "Hegemonic Rhythms: the Role of Hip-Hop Music in 21 Century American Public Diplomacy”, Ph.D. diss., Clark Atlanta University.

Khabeer, S.A. (2007) "Rep that Islam: The Rhyme and Reason of American Islamic Hip Hop”, The Muslim World, 97(1): pp. 25-141.

Keyes, C.L. (1996) "At the crossroads: Rap music and its African nexus", Ethnomusicology, 40(2): pp. 223-248.

Keyes, C.L. (2002) Rap Music and Street Consciousness, Chicago: University of Illinois Press.

Kinzer, S. (2006) Overthrow: America's Century of Regime Change from Hawaii to Iraq, Times Books.

Mauch, M, R.M. MacCallum, M. Levy and A.M. Leroi (2015) “The Evolution of Popular Music: USA 1960-2010”, Royal Society Open Science, 2: pp. 1-10.

Motley, C.M. and G.R. Henderson (2008) “The Global Hip-Hop Diaspora: Understanding the Culture", Journal of Business Research, 61: pp. $243-253$.

Nielson, E. (2013) “High Stakes for Hip-Hop Studies", The Huffington Post, last April 29, [online] Available at: http://www.huffingtonpost. com/erik-nielson/high-stakes-for-hip-hop-studies_b_3170794.html [Accessed 30 April 2016]. 
Nye, J.S. (1990) Bound to Lead: The Changing Nature of American Power, Basic Books.

Nye, J.S. (2004) Soft Power: The Means to Success in World Politics, New York: Public Affairs.

Nye, J.S. (2008) "Public Diplomacy and Soft Power", The Annals of the American Academy of Political and Social Science, 616, pp. 94-109.

Pew Research Center (2008) Global Public Opinion in the Bush Years (20012008), [online] Available at: http://www.pewglobal.org/2008/12/18/ global-public-opinion-in-the-bush-years-2001-2008/ [Accessed 30 April 2016].

Price, E.G. III (2006) Hip Hop Culture, Santa Barbara: ABC Clio.

RHHR (2013) "Government Spying and Surveillance from 'Hip-Hop Cops' to the N.S.A.”, July 13, [online] Available at: http://rhhr. org/2013/07/11/government-spying-and-surveillance-from-the-hiphop-cops-to-the-n-s-a/ [Accessed 30 April 2016].

Roberts, W.R. (2006) “The Evolution of Diplomacy", Mediterranean Quarterly, 17(3): pp. 55-64.

Samy A.H. (2006) Roc the Mic Right: The Language of Hip Hop Culture, New York: Routledge.

Sedgwick, M. (2010) "The Concept of Radicalization as a Source of Confusion", Terrorism and Political Violence, 2(4): pp.479-494.

Schneider, C.P. (2006) "Cultural Diplomacy: Hard to Define, but You'd Know It If You Saw It”, Brown Journal of World Affairs, 13(1): pp. 191-203.

Schneider, C P. (2008) “The Sound of Music in Pyongyang” Brookings, February 28, [online] Available at: http://www.brookings.edu/ research/opinions/2008/02/28-diplomacy-schneider [Accessed 30 April 2016].

Sharp, G. (1973) The Politics of Nonviolent Action (3 Vol.), Boston: Porter Sargent Publishers.

Sharp, G. (2005) Waging Nonviolent Struggle, Boston: Porter Sargent Publishers.

Snow, N. (2003) Information war: American propaganda, free speech and opinion control since 9-11, New York: Seven Stories Press.

Söderman, J. (2013) “The formation of 'Hip-Hop 'Academicus' - how American scholars talk about the academisation of hip-hop", British Journal of Music Education, 30(3): pp. 369-381.

Toop, D. (1999) Rap Attack: From African Jive to New York Hip Hop, London: Pluto Press. 
Tuch, H. (1990) Communicating with the World: US public diplomacy overseas, New York: St. Martin's.

"U.S. Diplomacy: Hitting the Right Notes" (2010) CBS News, April 04, [online] Available at: http://www.cbsnews.com/news/us-diplomacyhitting-the-right-notes/ [Accessed 30 April 2016].

US Department of State (2005) "Cultural diplomacy: the linchpin of public diplomacy", Report of the advisory committee on cultural diplomacy.

Walton, O. (1972) Music: Black, White \& Blue: A Sociological Survey of the Use and Misuse of Afro-American Music, William Morrow. 